International Journal of Advanced Technology in Mechanical, Mechatronics and Materials

(IJATEC)

Vol. 01, No. 1 (2020) 1-5

(C) Institute for Research on Innovation and Industrial System (IRIS)

\title{
Analysis of Fuel Injection Pressure Effect on Diesel Engine Combustion Opacity Value
}

\author{
Andi F. Sudarma*, Hadi Pranoto, Mardani A. Sera, Amiruddin Aziz \\ aDepartment of Mechanical Engineering Faculty of Engineering, Universitas Mercu Buana, Jakarta, Indonesia
}

\begin{abstract}
The use of diesel engines for vehicle applications has expanded for decades. However, it produces black smoke in the form of particulate matter contains fine and invisible particles during operation. The popular method for measuring the smoke opacity is by using a smoke meter for its simplicity and less costly. Fuel injection pressure is one of the parameters that affect the emission significantly, and the proper nozzle adjustment can reduce the density of exhaust gases and improve the engine performance. The purpose of this study is to determine the optimum fuel spray pressure that produces the lowest opacity value and analyse the effect of fuel spray pressure on the opacity value at a different engine speed. The present experiment uses the Hyundai D4BB engine, and the pressure variations were implemented on the injector nozzle at 125,130 , and $135 \mathrm{~kg} / \mathrm{cm} 2$. The engine was also tested with various engine idle speed, i.e., 1000, 1500, 2000, and $2500 \mathrm{rpm}$. It has been found that the optimum distance of fuel spraying is $147.679 \mathrm{~mm}$ with injector nozzle pressure $130 \mathrm{~kg} / \mathrm{cm} 2$, and the value of opacity is $9.51 \%$.
\end{abstract}

Keywords: diesel engine; biodiesel; injection pressure; emissions; smoke opacity

DOI: $10.37869 /$ ijatec.v1i1.6

Received 29 February 2020; Accepted 20 March 2020; Available online 30 March 2020

(C) 2020 IRIS Publisher. All rights reserved.

\section{Introduction}

Even though the efficiency of internal combustion engine is low [1], the use of diesel engines for vehicle application has expanded since the late 15th century [2]. Not only for transportation, but diesel engines are also widely used in various fields such as agriculture and engineering machinery for its durability and reliability. However, diesel engines produce more air pollution that affects the health condition [3]. Diesel engines produce fine particles, harmful gases, and polycyclic hydrocarbons that are very dangerous for health. Therefore, innovative development and research has been conducted widely to reduce the emission [4].

The emissions produced from the engine in the form of particulate matter (PM) contain fine and invisible particles. Poor engine condition and maintenance, low-quality fuel, and improper combustion Air Fuel Ratio (AFR) can all cause high amount of emissions [5]. The popular method for measuring the smoke opacity is by using a smoke meter for its simplicity and less costly. The instrument utilizes the physical phenomena of the smoke by measuring the extinction (scattering and absorption) of the transmitted light beam. However, some issues have been reported during the smoke opacity meter application on the advance engines, such as insufficient resolution, crosssensitivity to nitrogen dioxide and insensitivity to small particles [6].

Recently, several studies have been conducted to measure opacity level on diesel engines. A diesel engine (Mitsubishi L300 type) has been studied by Ichsan et al. [7] to know the effect of injection pressure on the opacity value. The engine was tested at various injection pressure, i.e. 110, 110, and $120 \mathrm{~kg} / \mathrm{cm} 2$. The investigation result shows that the injection pressure at $120 \mathrm{~kg} / \mathrm{cm} 2$ produces the

*Corresponding author: andi.firdaus@mercubuana.ac.id ISSN: 2720-9008 
lowest opacity value. The similar experiment also has been reported by Karthic et al. [8]. The work investigates a diesel engine which operated at a constant speed of $1500 \mathrm{rpm}$ at various fuel injection pressures, i.e. 200, 220, 240 and 260 bar using B30 biodiesel fuel. The experimental result shows that hydrocarbon and carbon monoxide emissions reduction has been found to be $46.15 \%$ and $15.9 \%$ respectively compared to static fuel injection conditions.

Fuel injector is a device for spraying diesel fuel in a very fine scattering mist into the combustion chamber. Fuel Injection Pressure (IP) and fuel injection timing are the parameters that affect the engine performance, combustion, and emission significantly [9]. Also, the proper nozzle adjustment can reduce the density of exhaust gases and improve the engine performance [10]. The main focus of the study was to investigate the effect of injection pressure on the smoke opacity level using a Hyundai D4BB type diesel engine. The engine was operated at various fuel injection pressure (125, 130 and $135 \mathrm{~kg} / \mathrm{cm} 2)$ and different constant speed $(1000,1500,2000$, and $2500 \mathrm{RPM})$.

\section{Experimental Setup and Procedure}

The experiment was carried out on the 4-cylinders diesel engine (Hyundai D4BB), and the smoke opacity was measured using an opacity smoke meter. The engine used for the experiment previously was dismantled from the vehicle and later on assembled on the testbed, as shown on Fig. 1. The major engine specifications are described in Table 1 [11].

Table 1. Engine specification

\begin{tabular}{lll}
\hline \multicolumn{3}{c}{ Hyundai D4BB Diesel Engine } \\
\hline Rated power & $28 / 1,800$ & $(\mathrm{ps} / \mathrm{rpm})$ \\
Engine displacement & 2,607 & (cc) \\
Compression ratio & $22: 1$ & \\
Standard injection pressure & 120 & $\left(\mathrm{~kg} / \mathrm{cm}^{2}\right)$ \\
Fuel Injection Pump & Bosch VE Type \\
\hline
\end{tabular}

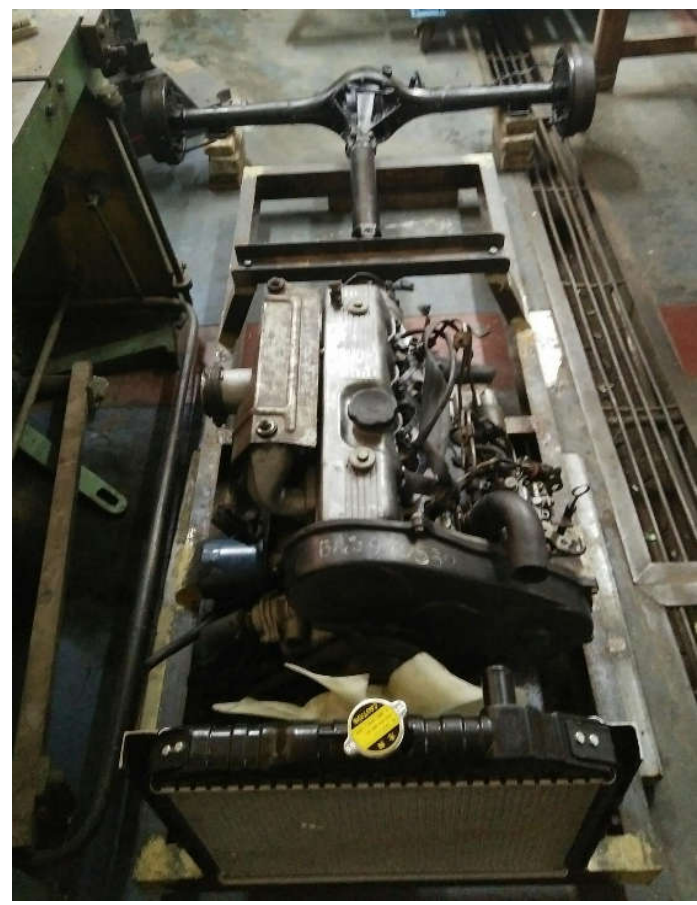

Figure 1. Diesel engine performance testbed 
The experiment was conducted using B30 biodiesel fuel. It was a blended of biofuel or Fatty Acid Methyl Ester (FAME) and petroleum diesel fuel in volumetric ratio 30:70. Furthermore, the fuel was delivered to the combustion room trough the swirl chamber for better fuel mixing by the Bosch VE injection pump. According to the shop manual [12], the factory standard IP was set at $120 \mathrm{~kg} / \mathrm{m} 2$, and pressure adjustment was allowed between $125-135 \mathrm{~kg} / \mathrm{m} 2$. Before the experiment, the IP of each injector was measured by standard nozzle tester (see Fig. 3), and then the engine was operated at various pressure, i.e., $125,130,135 \mathrm{~kg} / \mathrm{m} 2$. At this point, the opacity level was measured using automotive opacity smoke meter for different engine idle speed (i.e., 1000, 1500, 2000, and 2500), as shown in Fig. 4.

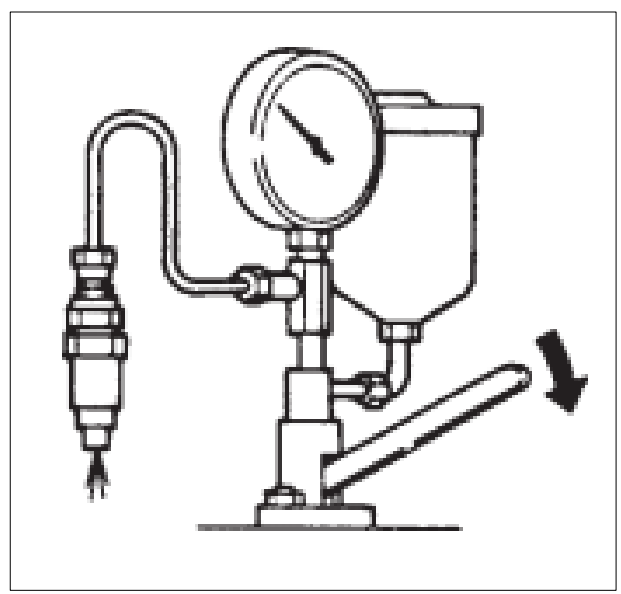

Figure 2. Nozzle tester

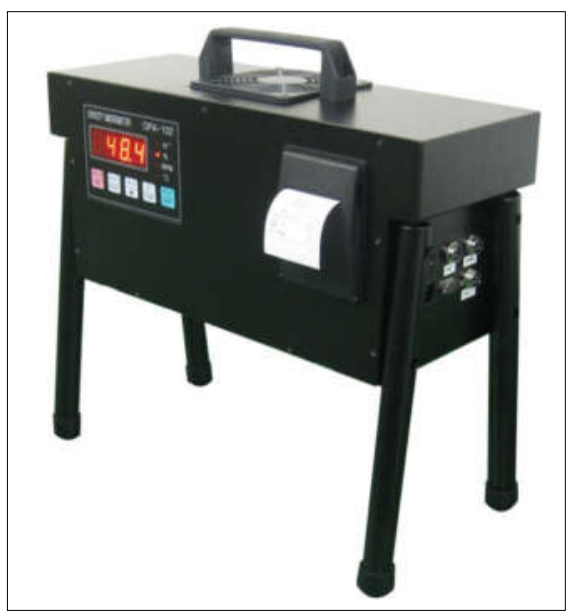

Figure 3. Automotive opacity smoke meter

\section{Results and Discussions}

The experimental results of the injection pressure effect on the smoke opacity level were reported and discussed in this section. The opacity was measured several times at various IP and idle speed. The readings were analyzed statistically using Student's $t$ test to evaluate the hypothesis of the samples [13].

The comparison of opacity mean values and engine speed at various injection pressure is shown on the Fig. 4. Opacities are typically expressed as a percentage value. $0 \%$ opacity represents clear air, and $100 \%$ opacity is the infinite smoke. The result shows that the highest opacity value was obtained by the IP $=125 \mathrm{~kg} / \mathrm{cm} 2$. Meanwhile, the adjustment at IP $=130 \mathrm{~kg} / \mathrm{cm} 2$ gives the best opacity level. The smokes produce by the diesel engine was the result of over-rich AFR or partially evaporated fuel [14]. When the fuel injection was over-pressured, the fuel droplet sprayed into the chamber in nanostructure size and unable to mix with air properly to form a homogenous mixture, resulting in the incomplete combustion. 


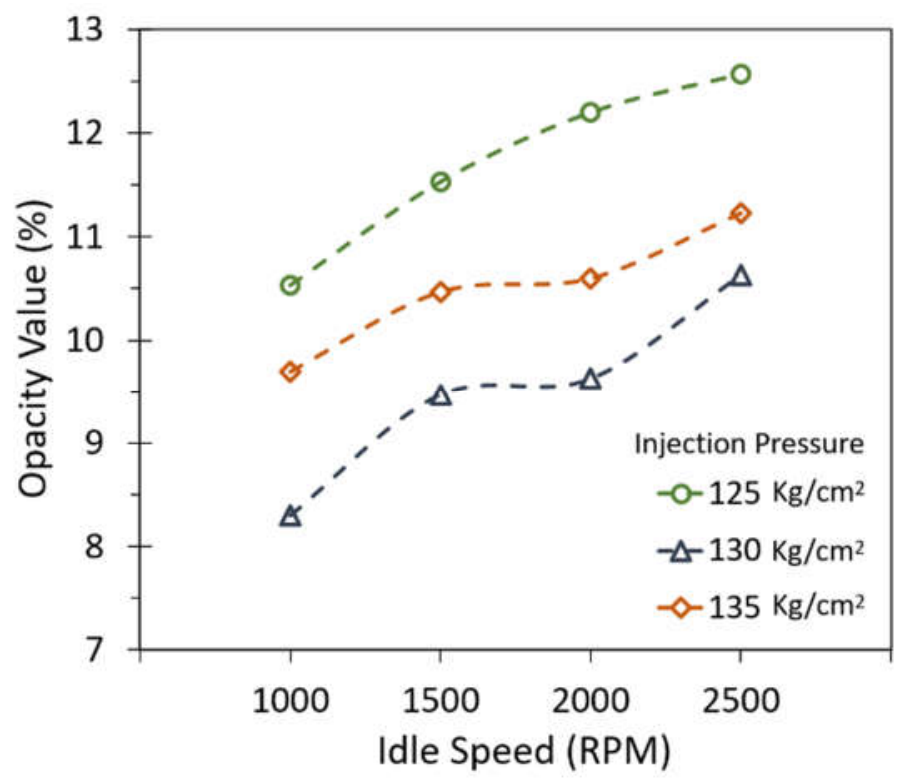

Figure 4. The comparison of opacity value and engine speed

The results show that that the injector nozzle pressure $125 \mathrm{~kg} / \mathrm{cm} 2$ obtained an average opacity value of $11,71 \%$, the pressure of the injector nozzle $130 \mathrm{~kg} / \mathrm{cm} 2$ obtained an average opacity value of $9,51 \%$, and at the pressure of the injector nozzle, $135 \mathrm{~kg} / \mathrm{cm} 2$ obtained opacity value of 10,50\%. Meanwhile, the opacity test results at various engine speeds show that the opacity value was increased along with engine speed increment.

\section{Conclusions}

The effect of fuel injection pressure has been evaluated using a smoke opacity meter at various engine speeds. Based on the experimental results, the optimum fuel injection pressure adjustment for Hyundai D4BB diesel engine, where at $130 \mathrm{~kg} / \mathrm{cm} 2$ with average combustion opacity value, is $9.51 \%$.

\section{References}

[1] M. A. Sera. Optimasi Daya Mesin dan Konsumsi Bahan Bakar Mesin Toyota Seri 5k melalui Penggunaan Pengapian Booster. Sinergi. 2015;19(3): 195-200.

[2] Z. Şahin, O. Durgun, and C. Bayram. Experimental Investigation of Gasoline Fumigation in A Single Cylinder Direct Injection (DI) Diesel Engine. Energy. 2008;33(8): 1298-1310.

[3] X. Wang, Y. Wang, Y. Bai, P. Wang, and Y. Zhao. An Overview of Physical and Chemical Features of Diesel Exhaust Particles. J. Energy Inst. 2019:92(6): 1864-1888.

[4] M. A. Sera, R. A. Bakar, and K. L. Sin. Effect of Fuel Density on the Performance of a CNG Fuelled Engine. Universiti Teknologi Malaysia; 2002.

[5] M. Mofijur, M. Rasul, N. M. S. Hassan, and M. N. Uddin. Investigation of Exhaust Emissions from A Stationary Diesel Engine Fuelled with Biodiesel," Energy Procedia. 2019:160: 791-797.

[6] W. A. Majewski and H. Jääskeläinen. Smoke Opacity. DieselNet Technol. Guid.; 2013.

[7] I. Nasution, M. Martias, and D. Fernandez. Pengaruh Perbedaan Variasi Tekanan Injektor Terhadap Ketebalan Asap (Opasitas) pada Motor Diesel L 300. Automot. Eng. Educ. Journals. 2015:1(2).

[8] S. V. Karthic, M. S. Kumar, G. Nataraj, and P. Pradeep. An Assessment on Injection Pressure and Timing to Reduce Emissions on Diesel Engine Powered by Renewable Fuel. J. Clean. Prod. 2020:255: 120186.

[9] S. Marčič, M. Marčič, M. Wensing, T. Vogel, and Z. Praunseis. A Simplified Model for A Diesel Spray. Fuel. 2018:222: 485-495.

[10] Hyundai Motor Company. The Family of Hyundai Engine. Hyundai; 2006. 
[11] A. F. Sudarma and M. H. Morsy. Numerical Study of Non-Premixed Air-Methane Swirl Combustor Flows Using RANS Method," in IOP Conference Series: Materials Science and Engineering. 2018:453(1).

[12] Hyundai Motor Company. Hyundai Model D4B Shop Manual. Hyundai; 2006.

[13] T. K. Kim. T Test as A Parametric Statistic," Korean J. Anesthesiol; 2015.

[14] H. C. Grigg and M. H. Syed. The Problem of Predicting Rate of Heat Release in Diesel Engines. in Proceedings of the Institution of Mechanical Engineers, Conference Proceedings, 1969:184(10): 192202. 